\title{
ANALISIS HAMBATAN PERKEMBANGAN STADIUM PLASMODIUM FALCIPARUM TERHADAP PEMBERIAN EKSTRAK DAUN SALAM BADAK (ACMENA ACUMINATISSIMA) IN VITRO
}

Laura Wihanto ${ }^{1)}$, Hilkatul Ilmi ${ }^{2)}$, Lidya Tumewu' ${ }^{2)}$, Aty Widyawaruyanti ${ }^{2), 3)}$, Achmad Fuad

$$
\text { Hafid }^{2), 3)} \text {, Indah Tantular }{ }^{2), 4)}
$$

\begin{abstract}
Background: The urgency generated by drug-resistant strains of malaria parasites has accelerated the need to find a new anti-malarial drug. Recent studies have shown that $80 \%$ ethanol extract Acmena acuminatissima has suitable antimalarial activities. Aim: To analyze the inhibitory effect of $A$. acuminatissima extract at the developmental stage of $P$. falciparum in infected erythrocytes in vitro. Methods: the synchronized culture of P. falciparum was incubated along with A. acuminatissima extract, and compared with negative controls. The effect on parasite growth was determined by observing the level of parasitemia and accumulation of various infective stages seen on thin blood smears after the incubation period of 12, 24, 36, and 48 hours using a light microscope with 1000 times magnification. Results: Within 48 hours of observation the difference was mainly in the proportion of ring-stage which was $2.75 \%$ in culture with the test compound and $41.41 \%$ in the negative control which showed that ethanol extract of A. acuminatissima inhibited the growth of parasites at the schizont stage into the ring stage. In trophozoite and schizonts stages of culture with test compounds, enlargement of digestive vacuole and vesiculation is obtained. Conclusion: A. acuminatissima inhibits the development of intraerythrocyt parasites at the schizonts stage and induced morphological changes.
\end{abstract}

Keyword: Malaria, Acmena Acuminatissima, Plasmodium Falciparum, Stage Development

\begin{abstract}
ABSTRAK
Pendahuluan: Kejadian resistensi strain parasit malaria terhadap obat mengindikasikan semakin terdesaknya kebutuhan untuk menemukan obat anti malaria yang baru. Studi terakhir menunjukkan bahwa ekstrak etanol 80\% Acmena acuminatissima memiliki aktivitas antimalaria yang tergolong baik. Tujuan: Menganalisis efek penghambatan ekstrak $A$. acuminatissima terhadap tahapan perkembangan $P$. falciparum pada eritrosit terinfeksi secara in vitro. Metode: Biakan $P$. falciparum yang telah disinkronisasi diinkubasi bersama dengan ekstrak A. acuminatissima, dan dibandingkan dengan kontrol negatif. Efek pada pertumbuhan
\end{abstract}


parasit ditentukan dengan mengamati tingkat parasitemia dan akumulasi berbagai stadium infektif yang berbeda yang dilihat pada hapusan darah tipis setelah masa inkubasi 12, 24, 36, dan 48 jam menggunakan mikroskop cahaya dengan pembesaran 1000 kali. Hasil: Dalam 48 jam pengamatan perbedaan terutama pada proporsi stadium cincin yaitu 2,75\% pada kultur dengan senyawa uji dan $41,41 \%$ pada kontrol negatif yang menunjukkan bahwa ekstrak etanol A. acuminatissima menghambat pertumbuhan parasit pada stadium skizon menjadi stadium cincin. Pada parasit stadium trofozoit dan skizon kultur dengan senyawa uji didapatkan pembesaran vakuola digestif dan gambaran vesikulasi. Kesimpulan: A. acuminatissima menghambat perkembangan parasit intraeritrositik pada stadium skizon dan menyebabkan terjadinya perubahan morfologi.

Kata Kunci : Malaria, Acmena Acuminatissima, Plasmodium Falciparum, Tahapan Perkembangan Stadium

\footnotetext{
1) Departemen Mikrobiologi dan Parasitologi, Fakultas Kedokteran Universitas Katolik Widya Mandala Surabaya, Jl. Raya Kalisari Selatan No.1 Tower A Lt.6 Pakuwon City Surabaya, Email korespondensi: laura_wihanto@hotmail.com, 2) Institute of Tropical Disease, Universitas Airlangga, Surabaya, 3) Departemen Farmakognosi dan Fitokimia, Fakultas Farmasi Universitas Airlangga, Surabaya, 4) Departemen Parasitologi, Fakultas Kedokteran Universitas Airlangga, Surabaya
}

\section{PENDAHULUAN}

Malaria merupakan salah satu ancaman patogen terbesar yang mendapat prioritas kesehatan internasional di abad 21(1). Insiden malaria di dunia menurut World Health Organization diperkirakan mencapai 214 juta kejadian dengan kematian mencapai 438.000 orang di tahun 2015. Kematian akibat malaria ini terutama terjadi pada bayi dan anak di bawah usia 5 tahun yaitu sebesar 306.000 kematian (70\%) dan 292.000 di antaranya (89\%) terjadi di sub-Sahara Afrika atau dengan kata lain terjadi satu kematian anak setiap dua menit di Afrika (2).

Di Indonesia angka kejadian malaria masih relatif tinggi dan $80 \%$ berasal dari 5 provinsi di wilayah timur Indonesia yaitu Papua, Papua Barat, Nusa Tenggara Timur, Maluku, dan Maluku Utara (3) .

Berbagai upaya telah dilakukan untuk menekan angka kesakitan dan kematian akibat malaria yang meliputi diagnosis dini, pengobatan cepat dan tepat, kemoprevensi (pemberian profilaksis), surveilans dan pengendalian vektor yang kesemuanya ditujukan untuk memutus mata rantai penularan malaria. Angka kejadian malaria dilaporkan menurun hingga lebih dari separuh pada dekade terakhir namun kendala untuk pemberantasan malaria juga semakin bertambah. Salah satu yang harus 
diwaspadai adalah ancaman resistensi Plasmodium terhadap pengobatan. Indikasi resistensi terhadap artemisinin telah terdeteksi di lima negara di area Mekong Besar yaitu Kambodia, Lao People's Democratic Republic, Myanmar, Thailand, dan Vietnam $(2,4)$.

Kebutuhan untuk mencari senyawa lain yang berpotensi dalam pemberantasan malaria adalah masalah mendesak yang harus senantiasa diselidiki. Keanekaragaman hayati Indonesia yang merupakan terbesar kedua di dunia setelah Brazil, sangat berpotensi untuk digali, diteliti dan dikembangkan dalam upaya menemukan komponen antimalaria baru yang poten (5).

\section{Acmena acuminatissima atau salam} badak adalah tanaman yang banyak ditemukan di berbagai wilayah di Indonesia. Pada penelitian terdahulu, didapatkan bahwa dalam ekstrak etanol $80 \%$ daun Acmena acuminatissima terkandung bahan kimia terpenoid, antrakinon, flavonoid, dan polifenol serta dalam pengujian sebagai antimalaria didapatkan nilai IC50 yang tergolong dalam kriteria moderat sehingga cukup prospektif dalam rangka pengembangan bahan alam Indonesia menjadi obat herbal terstandar dan fitofarmaka antimalaria (6-8).

Pada penelitian ini akan dilakukan uji ekstrak etanol $80 \%$ daun Acmena acuminatissima terhadap parasit $P$. falciparum strain 3D7 secara in vitro untuk mengevaluasi aktivitas antimalaria dan pengaruhnya terhadap tahapan perkembangan stadium $P$. falciparum di dalam darah. Daya kerja selektif terhadap stadium tertentu pada siklus hidup parasit diharapkan memberi petunjuk mengenai mekanisme kerja senyawa aktif antimalaria yang sesungguhnya yang terkandung di dalam ekstrak (9).

\section{METODE PENELITIAN}

\section{Bahan Penelitian}

Sampel yang digunakan adalah kultur Plasmodium falciparum strain 3D7 (sensitif klorokuin) dalam bentuk simpanan beku dan ekstrak etanol 80\% daun Acmena acuminatissima yang diperoleh dari laboratorium Science and Technology Research Partnership for Sustainable Development (SATREPS) Institute of Tropical Disease (ITD) - Universitas Airlangga, Surabaya. Bahan-bahan lain adalah RPMI 1640, HEPES buffer, natrium bikarbonat (NaHCO3), hipoksantin, gentamisin, serum dan eritrosit golongan $\mathrm{O}$, natrium klorida $(\mathrm{NaCl})$, aquadest steril, dimetilsulfosida (DMSO), pewarna giemsa, minyak emersi, dan sorbitol.

\section{Uji ekstrak terhadap tahapan perkembangan stadium}

Dalam pengujian ekstrak terhadap tahapan perkembangan stadium $P$. falciparum, tingkat parasitemia awal yang diperlukan adalah $1 \%$ dengan $5 \%$ 
hematokrit. Suspensi parasit dibuat dari kultur $P$. falciparum yang dibiakkan menurut metode Trager dan Jansen (1976) (10-12) kemudian disinkronisasi sehingga semua parasit berada pada stadium cincin menggunakan sorbitol 5\% (13).

Bahan uji yang digunakan adalah ekstrak etanol $80 \%$ daun Acmena acuminatissima dengan konsentrasi $1 \mu \mathrm{g} / \mathrm{ml}$ yang mampu menghambat sekitar 70-80\% pertumbuhan parasit secara in vitro berdasarkan hasil uji aktivitas antimalaria (7). Suspensi parasit diinkubasi bersama bahan uji dan kontrol menggunakan lempeng sumur mikro dengan 24 lubang.

Pengamatan dilakukan setiap 12 jam dengan membuat hapusan darah tipis pada jam ke-0, 12, 24, 36, dan 48. Hapusan difiksasi menggunakan metanol absolut dan dikeringkan. Pewarnaan memakai giemsa konsentrasi $20 \%$ kemudian diamati di bawah mikroskop cahaya dengan pembesaran 1000X menggunakan minyak emersi.

Pada kondisi normal, apabila tidak terjadi hambatan pertumbuhan dan perkembangan, maka stadium parasit akan berkembang dari stadium cincin menjadi trofozoit, dan dilanjutkan dengan stadium skizon dalam waktu 48 jam sesuai dengan siklus hidup normal parasit P. falciparum.

Penghitungan parasitemia dilakukan pada masing-masing stadium pada jam-jam tersebut di atas per 5000 eritrosit. Kriteria stadium parasit ditetapkan sebagai berikut: stadium cincin memiliki bentukan seperti cincin dengan inti 1-2, stadium trofozoit memiliki komponen sitosol dan pigmen serta inti tunggal, dan stadium skizon memiliki bentukan post mitosis dengan inti dua atau lebih $(14,15)$.

Hasil parasitemia yang didapat pada masing-masing stadium dibandingkan antara senyawa uji dan kontrol. Pengamatan dievaluasi menggunakan rumus berikut(6) :

$$
\% \text { Parasitemia }=\frac{\Sigma \text { Eritrosit Terifeksi }}{5000 \text { Eritrosit }} \times 100 \%
$$

$\%$ Pertumbuhan $=\%$ Parsitemia $-\%$ Parasitemia Jam ke -0

$$
\% \text { Penghambatan }=100 \%-\frac{X p}{X k n} \times 100 \%
$$

Keterangan :

$\mathrm{Xp}=$ Parasitemia uji

$\mathrm{Xkn}=$ Parasitemia kontrol negatif

\section{HASIL DAN PEMBAHASAN}

Pada pengamatan setelah 12 jam masa inkubasi kultur yang diberi ekstrak memiliki stadium cincin yang lebih sedikit dibandingkan kontrol negatif sedangkan stadium trofozoit dan skizon relatif sama. Hal ini berarti jumlah merozoit yang menginvasi eritrosit baru untuk menjadi stadium cincin dari stadium skizon sebelumnya berkurang dibandingkan kontrol negatif. 
Tabel 1. Persen Parasitemia Berdasarkan Stadium Parasit Pada Setiap Waktu Pengamatan

\begin{tabular}{cccccccc}
\hline \multirow{2}{*}{ Bahan Uji } & $\begin{array}{c}\text { Waktu } \\
\text { (jam) }\end{array}$ & \multicolumn{2}{c}{$\begin{array}{c}\% \text { Parasitemia } \\
\text { stadium parasit }\end{array}$} & $\begin{array}{c}\% \\
\text { Parasitemia }\end{array}$ & $\begin{array}{c}\% \\
\text { Pertumbuhan }\end{array}$ & $\begin{array}{c}\% \\
\text { Hambatan }\end{array}$ \\
\cline { 3 - 6 } & 0 & 0,62 & 0,03 & 0,12 & 0,77 & 0 & 0 \\
Kontrol negatif & 12 & 0,45 & 0,56 & 0,03 & 1,04 & 0,27 & 0 \\
& 24 & 0,27 & 0,72 & 0,59 & 1,58 & 0,81 & 0 \\
& 36 & 1,98 & 0,38 & 0,76 & 3,12 & 2,35 & 0 \\
& 48 & 4,21 & 1,46 & 0,15 & 5,82 & 5,05 & 0 \\
\hline \multirow{4}{*}{ Ekstrak } & 0 & 0,62 & 0,03 & 0,12 & 0,77 & 0 & 0 \\
& 12 & 0,32 & 0,58 & 0,03 & 0,93 & 0,16 & 10,63 \\
& 24 & 0,15 & 0,51 & 0,61 & 1,27 & 0,5 & 19,37 \\
& 36 & 1,37 & 0,16 & 0,65 & 2,18 & 1,41 & 30,13 \\
& 48 & 2,75 & 0,56 & 0,10 & 3,41 & 2,64 & 41,41 \\
\hline
\end{tabular}

Pada jam berikutnya kultur yang diberi ekstrak tetap memiliki stadium cincin yang lebih sedikit dibandingkan kontrol negatif dan selisihnya menjadi semakin besar. Stadium trofozoit dan skizon juga menjadi lebih kecil dibandingkan kontrol negatif namun kondisi ini kemungkinan disebabkan proporsi stadium sebelumnya memang lebih rendah, dalam artian stadium trofozoit dan skizon lebih rendah pada kultur dengan perlakuan ekstrak dibandingkan kontrol negatif karena pada pengamatan waktu sebelumnya stadium cincin dan trofozoit pada kultur dengan perlakuan ekstrak sudah lebih rendah dibandingkan kontrol negatif.

Pada pengamatan setelah 48 jam masa inkubasi, nampak perbedaan pada ketiga jumlah stadium baik cincin, trofozoit, maupun skizon yang ditunjukkan pada Tabel 1.

Ketiganya lebih sedikit pada kultur yang diberi ekstrak dibandingkan kondisi normal tanpa bahan uji. Perbedaan terutama pada proporsi stadium cincin yaitu $2,75 \%$ pada kultur dengan senyawa uji dan $41,41 \%$ pada kontrol negatif. Hasil tersebut menunjukkan bahwa ekstrak etanol $A$. acuminatissima menghambat pertumbuhan parasit pada stadium skizon menjadi stadium cincin.

Pada pengamatan morfologi menggunakan mikroskop cahaya (Nikon) dengan pembesaran 1000x terhadap biakan yang diinkubasi ekstrak, bentukan cincin relatif normal dan tidak berbeda dengan bentukan cincin pada biakan kontrol negatif pada semua waktu pengamatan. 

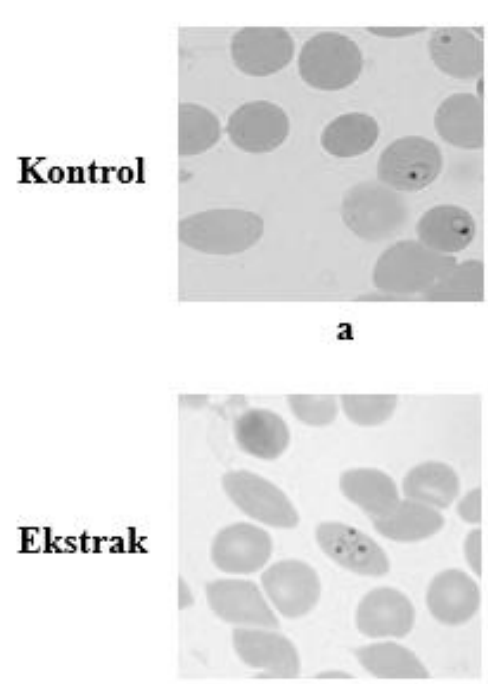

e
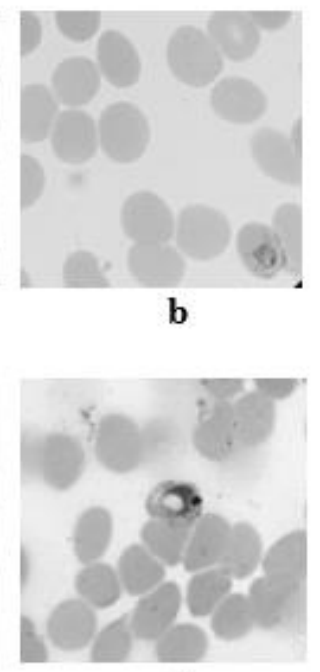

f

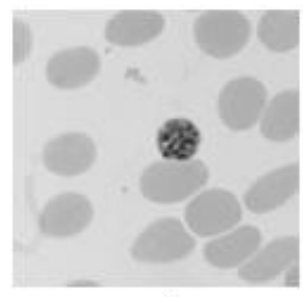

c

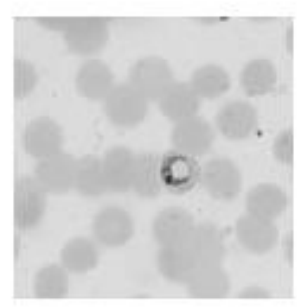

g

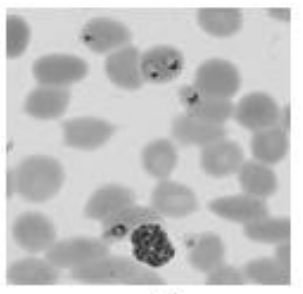

d

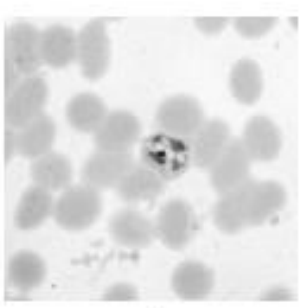

h

Gambar 1. Morfologi $P$. falciparum setelah diinkubasi bersama ekstrak etanol $A$. Acuminatissima. Bentuk cincin (e) nampak tidak ada perbedaan dibandingkan kontrol. Bentuk trofozoit dan skizon nampak vakuola digestif membesar berwarna jernih hampir memenuhi sitosol (f, g) dan terjadi vesikulasi yaitu sitoplasma mengalami vakuolisasi dengan bentukan vesikel-vesikel (h). Pigmen hemozoin nampak berwarna lebih gelap (f, g, h)

Perubahan morfologi parasit didapatkan terutama pada bentuk trofozoit dan skizon yaitu sitosol parasit menipis dan jernih di bagian tengah dan vakuola digestif membesar berbentuk bulat dengan batas tegas pada sitoplasma parasit, yang beberapa membesar hampir memenuhi seluruh sitoplasma.

Vakuola digestif diperkirakan merupakan vesikel yang khusus diperuntukkan untuk proses degradasi hemoglobin parasit. Proses degradasi hemoglobin terutama terjadi pada stadium trofozoit dan skizon yang menunjukkan aktivitas metabolik terbesar. Proses ini memiliki peran vital sebagai sumber utama asam amino yang diperlukan untuk pertumbuhan dan perkembangan parasit
(16). Parasit di samping fungsi nutrisi, juga perlu mendegradasi hemoglobin untuk mengurangi volume dan mencegah lisis prematur dari eritrosit yang akan terjadi seiring perkembangan volume parasit (17).

Pembesaran vakuola digestif merupakan tanda patologis (18) yang mengindikasikan adanya kemungkinan ekstrak A. acuminatissima memiliki aktivitas antimalaria dengan menghambat proses degradasi hemoglobin dan atau akibat terhambatnya proses detoksifikasi heme sehingga terjadi penumpukan di dalam vakuola digestif. Gambaran vesikulasi parasit yaitu gambaran vesikel kecil multipel pada sitoplasma parasit. menandakan terjadinya degenerasi parasit. 
Ekstrak A. acuminatissima berdasarkan pengamatan terhadap tahapan perkembangan parasit mempengaruhi proses maturasi stadium trofozoit dan skizon menjadi bentuk yang tidak normal dan berakibat pada terhambatnya pembentukan merozoit baru dan pecahnya skizon.

\section{KESIMPULAN}

A. acuminatissima menghambat perkembangan parasit intraeritrositik pada stadium skizon. Perubahan morfologi yang tampak menyolok terutama terjadi pada stadium trofozoit dan skizon berupa pembesaran vakula digestif dan vesikulasi pada sitoplasma parasit.

\section{DAFTAR PUSTAKA}

1. Riley EM, Stewart VA. Immune mechanisms in malaria: new insights in vaccine development. Nat Med. 2013 Feb;19(2):168-78.

2. WHO. World Malaria Report 2015. World Health Organization. 2015;238.

3. Pusat Data dan Informasi Kementrian Kesehatan RI. InfoDatin-Malaria. Kementrian Kesehatan RI; 2016. 1-7 .

4. Klein EY. Antimalarial drug resistance: A review of the biology and strategies to delay emergence and spread. Int $\mathbf{J}$ Antimicrob Agents. 2013;41(4):311-7.

5. Dewoto HR. Pengembangan Obat Tradisional Indonesia Menjadi
Fitofarmaka . Maj Kedokt Indones. 2007;57(7):205-11.

6. Hafid AF, Puliansari N, Lestari NS, Tumewu L, Rahman A, Widyawaruyanti A. Skrining Aktivitas Antimalaria Beberapa Tanaman Indonesia Hasil Eksplorasi dari Hutan Raya Cangar, Batu-Malang, Jawa Timur. J Farm dan Ilmu Kefarmasian Indones. 2019;3(1):6-11.

7. Cahyaningsih, E. 'Kajian bahan aktif antimalaria dari daun Salam Badak (Acmena acuminatissima) terhadap Plasmodium falciparum in vitro', Tesis, Fakultas Farmasi Universitas Airlangga Surabaya, 2015

8. Wilcox M, Bodeker G, Rasoanaivo P. Traditional Medicinal Plants and Malaria: Guidelines for the Nonclinical Evaluation of the Efficacy of Traditional Antimalarials. Wilcox M, Bodeker G, Rasoanaivo P, editors. Florida: CRC Press, LLC, 2004. 266-67

9. Bhat GP, Surolia N. In vitro antimalarial activity of extracts of three plants used in the traditional medicine of India. Am J Trop Med Hyg. 2001;65(4):304-8.

10. Trager W, Jensen JB. Human Malaria Parasites in Continous Culture. Science. 1976;193(August):673-5.

11. Kunwittaya S, Treeratanapiboon L, Srisarin A, Isarankura-Na-Ayudhya C, Prachayasittikul V. In vitro study of 
parasite elimination and endothelial protection by curcumin: Adjunctive therapy for cerebral malaria. EXCLI J. 2014;13(Cm):287-99.

12. Gamo F-J, Sanz LM, Vidal J, de Cozar C, Alvarez E, Lavandera J-L, et al. Thousands of chemical starting points for antimalarial lead identification. Nature. 2010;465(7296):305-10.

13. Lambros C, Vanderberg JP. Synchronization of Plasmodium falciparum erythrocytic stages in culture. J Parasitol. 1979;65(3):418-20.

14. Bogitsh, B., Carter, C. and Oeltmann, T. Human parasitology. Burlington, MA: Elsevier Academic Press, 2013.116-25.

15. Farrar, J., Hotez, P., Junghanss, T., Kang, G., Lalloo, D. and White, N. Manson's tropical diseases. 3rd ed., Philadelphia: Elsevier Saunders, 2014. 532-66

16. Ihekwereme CP, Esimone CO, Nwanegbo EC. Hemozoin inhibition and control of clinical malaria. Adv Pharmacol Sci, 2014(45):1-7.

17. Coronado LM, Nadovich CT, Spadafora C. Malarial hemozoin: From target to tool. Biochim Biophys Acta Gen Subj, 2014;1840(6):2032-41.

18. Rosenthal PJ. Plasmodium falciparum: Effects of Proteinase Inhibitors on Globin Hydrolysis by Cultured Malaria
Parasites. Exp Parasitol. 1995 Mar $1 ; 80(2): 272-81$. 